\title{
Muco-Cutaneous Changes Following COVID-19 in Children
}

\author{
Elda Skenderi, Admir Sulovari, Gjeorgjina Kuli-Lito, Alberta Shkembi, Floreta Korumi, \\ Miranda Malaj
}

University Hospital Center "Mother Teresa”, Tirana, Albania

Email: elda_skenderi@yahoo.com

How to cite this paper: Skenderi, E., Sulovari, A., Kuli-Lito, G., Shkembi, A., Korumi, F. and Malaj, M. (2021) Muco-Cutaneous Changes Following COVID-19 in Children. Journal of Biosciences and Medicines, 9, 6-15.

https://doi.org/10.4236/jbm.2021.97002

Received: May 26, 2021

Accepted: July 5, 2021

Published: July 8, 2021

Copyright ( 2021 by author(s) and Scientific Research Publishing Inc. This work is licensed under the Creative Commons Attribution International License (CC BY 4.0).

http://creativecommons.org/licenses/by/4.0/

(c) (i) Open Access

\begin{abstract}
Coronavirus disease 2019 (COVID-19) is an illness caused by the novel coronavirus designated as severe acute respiratory syndrome coronavirus 2 (SARS-CoV-2). It was first identified in Wuhan, China, in December 2019, and soon spread all over the world causing a global pandemic. Since the beginning of the pandemic, fewer cases of COVID-19 have been reported in children than in adults. Most cases have been mild and only a small proportion of infected children needed hospitalization. As the pandemic evolved, it was soon evident that immune dysregulation inflicted by the virus, posed children at risk for their lives. It is still hard to predict its effects on children health and well-being. Here are reported a series of cases of muco-cutaneous changes following COVID-19 infection in children. Children ranged from 8 months to ten years. They had a history of a recent COVID-19 infection (1 - 3 months ago), with a RT-PCR for COVID-19 negative, SARS-CoV-2 IgM negative and a positive SARS-Cov-2 IgG. Their presentation was consistent with a late reaction to COVID-19 reaction with muco-cutaneous changes dominating the scenery.
\end{abstract}

\section{Keywords}

COVID-19, Rash, Immune Dysregulation, Children, Reaction

\section{Introduction}

Coronavirus disease 2019 (COVID-19) is an illness caused by the novel coronavirus, designated as severe acute respiratory syndrome coronavirus 2 (SARS-CoV-2). It was first identified in an outbreak of respiratory illness cases in Wuhan City, China, in December 2019. The virus soon spread all over the world, and on March 11, 2020 the World Health Organization (WHO) declared 
COVID-19 a global pandemic. Coronaviruses typically infect animals but some have evolved to infect humans, like SARS-CoV-2, which is postulated to have originated in a large animal seafood market. The principal mode of transmission of infection is through exposure to respiratory droplets or contaminated surfaces. Since the beginning of the pandemic, fewer cases of COVID-19 have been reported in children than in adults. The rate of asymptomatic children, ranging from $4.4 \%-23 \%$, is higher than reported in adults and probably much higher as many asymptomatic children are not screened [1] [2] [3] [4]. The clinical presentation in adults ranges from mild illness to severe pneumonia, acute respiratory distress syndrome, acute cardiac injury and thromboembolic complications. Patients with severe diseases have evidence of hiperimmune response with persistent fevers, elevated inflammatory markers and elevated proinflammatory cytokines [5] [6]. Common symptoms in children are cough, fever, shortness of breath, sore throat, diarrhea, myalgia, fatigue, rhinorrhea, vomiting, nasal congestion, abdominal pain, rash [7] [8] [9]. The rate of children with critical illness ranges from $0.4 \%$ - $9 \%$ of confirmed cases but some reports include patients diagnosed in hospital [2] [4] [10] [11]. Factors associated with severe disease in children are neonatal age group, male gender, lower respiratory tract disease and pre-existing medical conditions [4]. Differences between adults and children are as the result of changes in immune function and the angiotensin-converting enzyme (ACE) 2receptors, used by the virus to enter type II pneumocytes in the lung. The immune system of children is highly prepared to novel pathogens, due to high levels of innate IgM antibodies and the ability to rapidly produce natural antibodies with broad reactivity [12]. Other differences are proposed alterations in $\mathrm{T}$ cell populations in adults due to continuous antigen stimulation and thymic involution, varied levels of ACE-2 expression in children, and the simultaneous presence of other viruses in the respiratory mucosa of children, competing with SARS-CoV-2 [13]. Besides all these children have fewer comorbidities and a stronger pulmonary regenerative potential.

\section{Method \& Material}

This is a case-report series. Children were admitted in the General Pediatric Ward at the University Hospital Center "Mother Teresa", Tirana, Albania during October 2020-April 2021. The cases are enlisted according the time of admission.

\section{Case nr.1}

A 21 months old female presented at the University Hospital Center of Tirana with a skin rash; palpable, non-pruritic plaques, purple-colored in center, spread over the trunk, extremities and face and mild edema on the extremities (Figure 1). She had a family history of COVID-19 infection 3 - 4 months ago. On physical examination appeared irritable with moderate fever, colored lips and a strawberry tongue.

RT-PCR for COVID-19 was negative. SARS-CoV-2 IgM were negative and 
SARS-Cov-2 IgG were elevated $8.88(<0.8)$. Laboratory investigations on admission revealed a blood cell count of high WBC 19,000 cells $/ \mathrm{mm}^{3}$ (69\% neutrophils and $24.1 \%$ lymphocytes), RBC 4,270,000 cells $/ \mathrm{mm}^{3}$, Hemoglobin level $11.5 \mathrm{~g} / \mathrm{dL}$, Hematocrit value $33.1 \%$, normal Platelet count 272,000 cells $/ \mathrm{mm}^{3}$, Erythrocyte sedimentation rate $28 \mathrm{~mm} / \mathrm{h}(<15 \mathrm{~mm} / \mathrm{h})$, normal Aspartat aminotransferase 25 U/L (14 - $35 \mathrm{U} / \mathrm{L})$, and Alanin aminotransferase $15 \mathrm{U} / \mathrm{L}$ (9 - $24 \mathrm{U} / \mathrm{L})$, Creatin kinase $75 \mathrm{U} / \mathrm{L}$ (30 - $200 \mathrm{U} / \mathrm{L})$, normal Blood urea nitrogen $22.3 \mathrm{mg} / \mathrm{dL}$ (15 - 36 $\mathrm{mg} / \mathrm{dL})$, and Creatinine $0.53 \mathrm{mg} / \mathrm{dL}(0.44-0.64 \mathrm{mg} / \mathrm{dL})$, Serum total protein 7.5 $\mathrm{g} / \mathrm{dL}(6-8 \mathrm{~g} / \mathrm{dL})$, Albumin $4.5 \mathrm{mg} / \mathrm{dL}(3.2-4.5 \mathrm{mg} / \mathrm{dL})$, high $\mathrm{C}$ reactive protein $7.15 \mathrm{mg} / \mathrm{dL}(<0.5 \mathrm{mg} / \mathrm{dL})$, high D-dimer $2300 \mathrm{mg} / \mathrm{dL}(<198 \mathrm{mg} / \mathrm{dL})$, Fibrinogen activity $431 \mathrm{mg} / \mathrm{dL}(160$ - $390 \mathrm{mg} / \mathrm{dL})$, PT quick time 106\% (70\% - 110\%), Prothrombin time/international normalized ratio (INR) 0.96 (0.85 - 1.15), aPTT $28.7 \mathrm{sec}(24-35 \mathrm{sec})$.

Blood cultures were negative. Radiologic examination of the lungs and heart were normal. After a 5-day course of oral prednisolone the rash faded and inflammatory parameters were normalized.

\section{Case nr.2}

A 28 months old male presented at the hospital with an urticarial rash spread all over the body; face, trunk and extremities and peripheral edema on the hands and feet (Figure 2). He had a history of family COVID-19 infection over 3 months ago. On physical examination he appeared moderately ill, irritable with moderate fever, and a hyperemic pharynx. He had a RT-PCR for COVID-19 negative, SARS-CoV-2 IgM were negative and a positive SARS-Cov-2 IgG 3.0 $(<0.8)$.
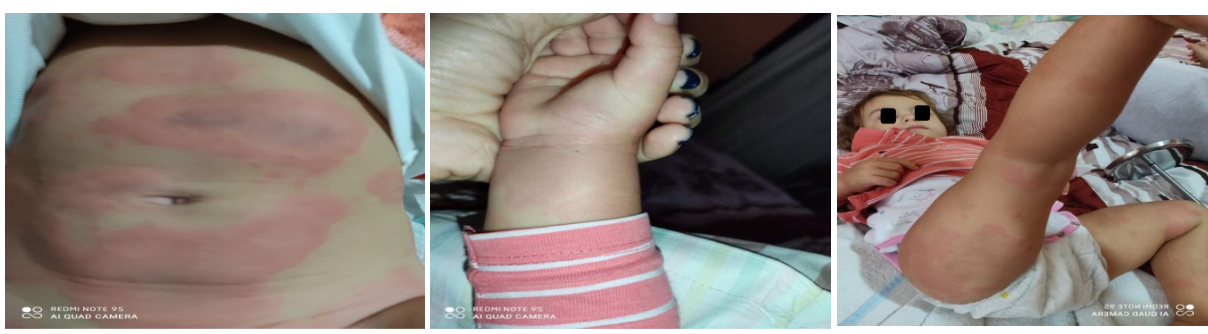

Figure 1. A 21 months female with post COVID-19 rash.
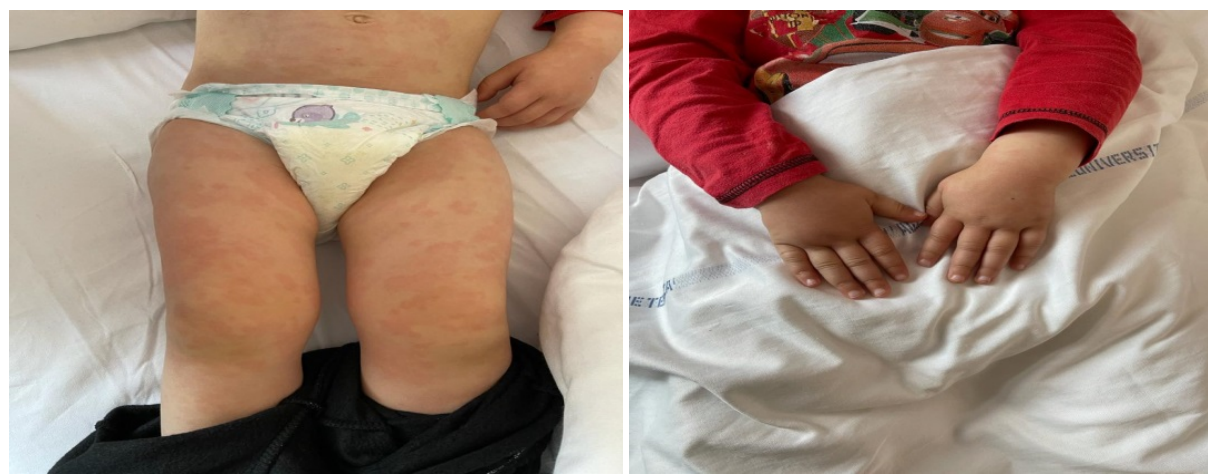

Figure 2. A 28 months old male with post COVID-19 rash. 
Laboratory investigations revealed a blood cell count of high WBC 25,000 cells $/ \mathrm{mm}^{3}$ (73\% neutrophils and $24.1 \%$ lymphocytes), RBC $3,750,000$ cells $/ \mathrm{mm}^{3}$, Hemoglobin level $10.5 \mathrm{~g} / \mathrm{dL}$, Hematocrit value $31.1 \%$, normal Platelet count 355,000 cells $/ \mathrm{mm}^{3}$, Erythrocyte sedimentation rate $25 \mathrm{~mm} / \mathrm{h}(<15 \mathrm{~mm} / \mathrm{h})$, normal Aspartat aminotransferase $17 \mathrm{U} / \mathrm{L}(14-35 \mathrm{U} / \mathrm{L})$, and Alanin aminotransferase $25 \mathrm{U} / \mathrm{L}(9-24 \mathrm{U} / \mathrm{L})$, Creatin kinase $155 \mathrm{U} / \mathrm{L}(30-200 \mathrm{U} / \mathrm{L})$, normal Blood urea nitrogen $25 \mathrm{mg} / \mathrm{dL}(15-36 \mathrm{mg} / \mathrm{dL})$, and Creatinine $0.5 \mathrm{mg} / \mathrm{dL}(0.44-0.64$ $\mathrm{mg} / \mathrm{dL})$, Serum total protein $7.0 \mathrm{~g} / \mathrm{dL}(6-8 \mathrm{~g} / \mathrm{dL})$, Albumin $4.5 \mathrm{mg} / \mathrm{dL}(3.2-4.5$ $\mathrm{mg} / \mathrm{dL})$, high $\mathrm{C}$ reactive protein $10.6 \mathrm{mg} / \mathrm{dL}(<0.5 \mathrm{mg} / \mathrm{dL})$, normal D-dimer 200 $\mathrm{mg} / \mathrm{dL}(<198 \mathrm{mg} / \mathrm{dL})$, Fibrinogen activity $331 \mathrm{mg} / \mathrm{dL}(160-390 \mathrm{mg} / \mathrm{dL})$, PT quick time $96 \%$ (7\% - 110\%), Prothrombin time/international normalized ratio (INR) 0.98 (0.85 - 1.15), aPTT $26.7 \mathrm{sec}(24-35 \mathrm{sec})$.

Blood cultures were negative. Radiologic examination of the lungs and heart were normal. After a 7-day course of intra-venous prednisolone and antibiotics, the rash faded and inflammatory parameters were normalized.

\section{Case nr.3}

An 8 months old male presented at the hospital with a widespread rash on the skin including palms of the hands and soles (Figure 3 ). He had a family history of COVID-19 over 2 months ago. On physical examination he appeared ill, irritable with high fever $40^{\circ} \mathrm{C}$, red cracked lips, conjunctivitis and a strawberry tongue. He had a RT-PCR for COVID-19 negative, SARS-CoV-2 IgM were negative and a positive SARS-Cov-2 IgG $6.8(<0.8)$.

On blood cell count there were found high WBC 28,600 cells $/ \mathrm{mm}^{3}$ (63\% neutrophils and $32 \%$ lymphocytes), RBC 4,150,000 cells $/ \mathrm{mm}^{3}$, Hemoglobin level $10.8 \mathrm{~g} / \mathrm{dL}$, Hematocrit value $34 \%$, high Platelet count $663,000 \mathrm{cells} / \mathrm{mm}^{3}$, Erythrocyte sedimentation rate $25 \mathrm{~mm} / \mathrm{h}(<15 \mathrm{~mm} / \mathrm{h})$. Biochemical panel revealed: normal Aspartat aminotransferase $37 \mathrm{U} / \mathrm{L}(14-35 \mathrm{U} / \mathrm{L})$, and Alanin aminotransferase $25 \mathrm{U} / \mathrm{L}(9-24 \mathrm{U} / \mathrm{L})$, Creatin kinase $55 \mathrm{U} / \mathrm{L}$ (30 - $200 \mathrm{U} / \mathrm{L})$, normal Blood urea nitrogen $25 \mathrm{mg} / \mathrm{dL}(15-36 \mathrm{mg} / \mathrm{dL})$, and Creatinine $0.5 \mathrm{mg} / \mathrm{dL}(0.44$ $0.64 \mathrm{mg} / \mathrm{dL})$, Serum total protein $6.9 \mathrm{~g} / \mathrm{dL}(6-8 \mathrm{~g} / \mathrm{dL})$, Albumin $3.5 \mathrm{mg} / \mathrm{dL}(3.2$ $4.5 \mathrm{mg} / \mathrm{dL})$, high C reactive protein $7.15 \mathrm{mg} / \mathrm{dL}(<0.5 \mathrm{mg} / \mathrm{dL})$, high D-dimer 700 $\mathrm{mg} / \mathrm{dL}(<198 \mathrm{mg} / \mathrm{dL})$, Fibrinogen activity $331 \mathrm{mg} / \mathrm{dL}$ (160 - $390 \mathrm{mg} / \mathrm{dL})$, PT quick time $100 \%(70 \%-110 \%)$, Prothrombin time/international normalized ratio (INR) 0.86 (0.85 - 1.15), aPTT $24.7 \mathrm{sec}(24-35 \mathrm{sec})$.

Blood cultures were negative. Radiologic examination of the lungs and heart revealed no abnormalities. After a 7-day course of intra-venous prednisolone and antibiotics, the rash faded and inflammatory parameters turned to normal.

Case nr.4

A 10 years old male presented at the hospital with an erythematous rash on the face and neck, a three day high fever and cough (Figure 4). He also had a history of family COVID-19 almost 2 months ago. On physical examination he appeared ill, tired with moderate fever and an injected pharynx. He had a RT-PCR for COVID-19 negative, SARS-CoV-2 IgM were negative and a positive SARS-Cov-2 IgG $3.8(<0.8)$. 


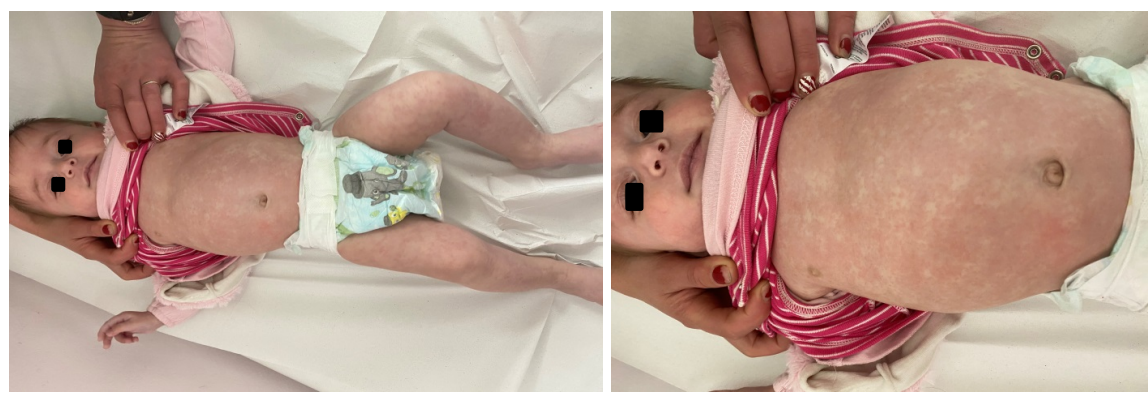

Figure 3. A 8 months old male with post COVID-19 rash.

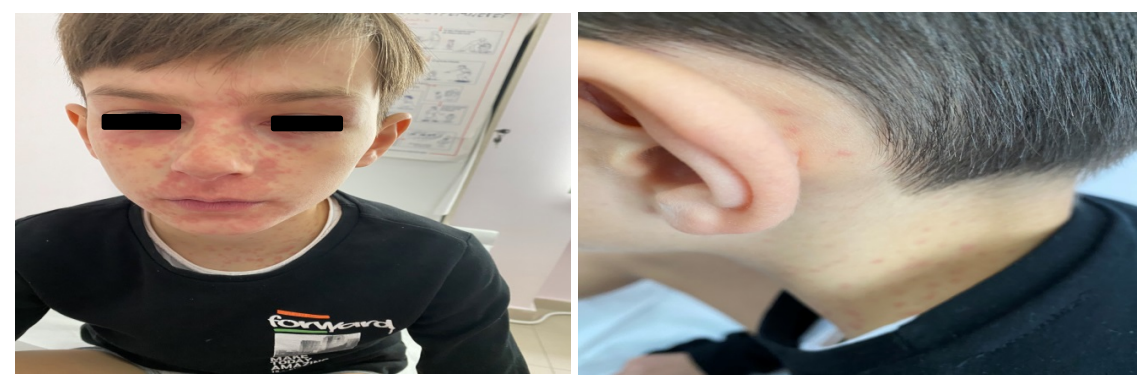

Figure 4. A 10 years old male with post COVID-19 rash.

Blood count showed high WBC 14,700 cells $/ \mathrm{mm}^{3}$ (82\% neutrophils and $14 \%$ lymphocytes), RBC 4,350,000 cells $/ \mathrm{mm}^{3}$, Hemoglobin level $12.5 \mathrm{~g} / \mathrm{dL}$, Hematocrit value $35.1 \%$, normal Platelet count 420,000 cells $/ \mathrm{mm}^{3}$, Erythrocyte sedimentation rate $30 \mathrm{~mm} / \mathrm{h}(<15 \mathrm{~mm} / \mathrm{h})$, normal Aspartat aminotransferase $29 \mathrm{U} / \mathrm{L}$ (14 - $35 \mathrm{U} / \mathrm{L}$ ), and Alanin aminotransferase $25 \mathrm{U} / \mathrm{L}$ ( 9 - $24 \mathrm{U} / \mathrm{L})$, Creatin kinase 255 U/L (30 - $200 \mathrm{U} / \mathrm{L})$, normal Blood urea nitrogen $25 \mathrm{mg} / \mathrm{dL}(15-36 \mathrm{mg} / \mathrm{dL})$, and Creatinine $0.45 \mathrm{mg} / \mathrm{dL}(0.44-0.64 \mathrm{mg} / \mathrm{dL})$, Serum total protein $8 \mathrm{~g} / \mathrm{dL}(6-8$ $\mathrm{g} / \mathrm{dL})$, Albumin $4 \mathrm{mg} / \mathrm{dL}(3.2-4.5 \mathrm{mg} / \mathrm{dL})$, high $\mathrm{C}$ reactive protein $4.16 \mathrm{mg} / \mathrm{dL}$ $(<0.5 \mathrm{mg} / \mathrm{dL})$, normal D-dimer $210 \mathrm{mg} / \mathrm{dL}(<198 \mathrm{mg} / \mathrm{dL})$, Fibrinogen activity $331 \mathrm{mg} / \mathrm{dL}$ (160 - $390 \mathrm{mg} / \mathrm{dL})$, PT quick time 86\% (70\% - 110\%), Prothrombin time/international normalized ratio (INR) 0.9 (0.85 - 1.15), aPTT $32 \mathrm{sec}(24-35$ sec).

Blood cultures were negative. Radiologic examination of the lungs and heart were normal. After a 3-day course of intra-venous prednisolone and antibiotics, the rash faded and inflammatory parameters normalized.

Case nr.5

A 9 months old female presented at the hospital with a history of 5-days high fever and an erythematous urticarial rash spread over the face, trunk, extremities and palms of the hands and soles (Figure 5). She had also a family history of COVID-19 almost 2 months ago. On physical examination she appeared ill, irritable with high fever, red-cracked lips, strawberry tongue, injected pharynx, and conjunctivitis.

She had a RT-PCR for COVID-19 negative, SARS-CoV-2 IgM were negative and a positive SARS-Cov-2 IgG $8.0(<0.8)$. Other laboratory investigations revealed a blood cell count of high WBC 20,300 cells $/ \mathrm{mm}^{3}$ (55.5\% neutrophils and 

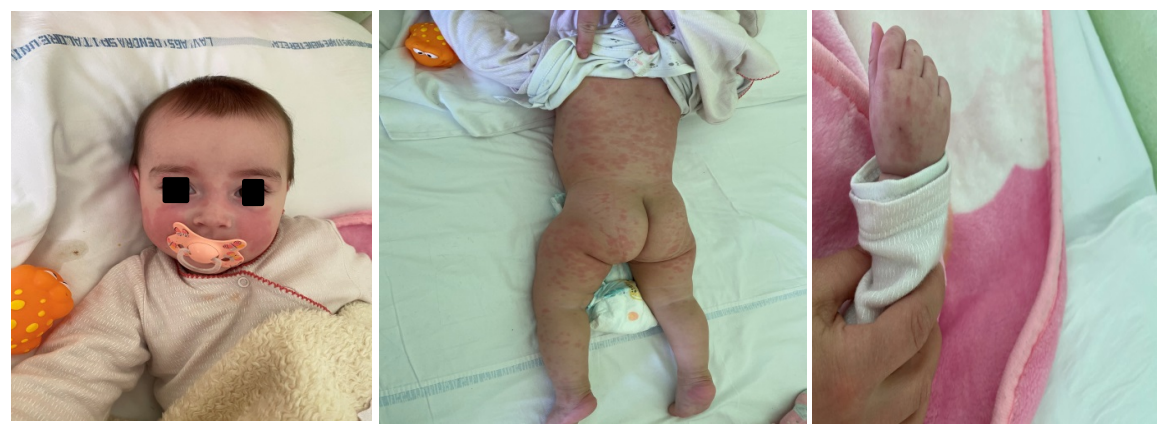

Figure 5. A 9 months old female with post COVID-19 rash.

$34.1 \%$ lymphocytes), RBC 4,000,000 cells $/ \mathrm{mm}^{3}$, Hemoglobin level $10.7 \mathrm{~g} / \mathrm{dL}$, Hematocrit value $34.1 \%$, high Platelet count 729,000 cells $/ \mathrm{mm}^{3}$, Erythrocyte sedimentation rate $27 \mathrm{~mm} / \mathrm{h}(<15 \mathrm{~mm} / \mathrm{h})$, normal Aspartat aminotransferase 17 U/L (14 - $35 \mathrm{U} / \mathrm{L}$ ), and Alanin aminotransferase $19 \mathrm{U} / \mathrm{L}$ ( 9 - $24 \mathrm{U} / \mathrm{L})$, Creatin kinase $180 \mathrm{U} / \mathrm{L}$ (30 - $200 \mathrm{U} / \mathrm{L})$, normal Blood urea nitrogen $35 \mathrm{mg} / \mathrm{dL}$ (15 - 36 $\mathrm{mg} / \mathrm{dL}$ ), and Creatinine $0.63 \mathrm{mg} / \mathrm{dL}(0.44-0.64 \mathrm{mg} / \mathrm{dL})$, Serum total protein 7.2 $\mathrm{g} / \mathrm{dL}(6-8 \mathrm{~g} / \mathrm{dL})$, Albumin $4.1 \mathrm{mg} / \mathrm{dL}(3.2-4.5 \mathrm{mg} / \mathrm{dL})$, high $\mathrm{C}$ reactive protein $5.8 \mathrm{mg} / \mathrm{dL}(<0.5 \mathrm{mg} / \mathrm{dL})$, high D-dimer $500 \mathrm{mg} / \mathrm{dL}(<198 \mathrm{mg} / \mathrm{dL})$, Fibrinogen activity $431 \mathrm{mg} / \mathrm{dL}(160-390 \mathrm{mg} / \mathrm{dL})$, PT quick time $101 \%(70 \%-110 \%)$, Prothrombin time/international normalized ratio (INR) 0.86 (0.85 - 1.15), aPTT $29 \sec (24-35 \mathrm{sec})$.

Blood cultures were negative. Radiologic examination of the lungs and heart were normal. After a 7-day course of intra-venous prednisolone and antibiotics, the rash faded and inflammatory parameters normalized and the child was play-full again.

\section{Discussion}

As the pandemic affected nearly all the world, pediatrician and parents were somehow consoled by the apparent fact that the health of children were in less risk than theirs, but while the pandemic evolved the number of children infected increased too. SARS CoV-2 infection is characterized by an initial cytokine storm that can result in acute respiratory distress syndrome which is characteristic of the severe disease in adults, but cases have been reported in children too. Children have a stronger innate immune response, higher proportion of total lymphocyte and absolute number of $\mathrm{T}$ and $\mathrm{B}$ cells, as well as natural killer cells, which play an important role in virus clearance [14] [15]. Children also have a less pro-inflammatory cytokine response, which make them less prone to develop acute respiratory distress syndrome. The initial phase of cytokine storm is then followed by a period of immune dysregulation which is accused for most of COVID-19 complications.

Since May 2020, several highly endemic countries reported a high incidence of multisystem inflammatory syndrome (MIS) in children. Several case definitions were proposed, all include fever, elevated inflammatory markers, and organ 
dysfunction not attributed to another infectious cause (Table 1) [16]. In the following months, as the pandemic evolved, there have been increasing reports from Europe, North America, Asia, and Latin America describing children and adolescents with COVID-19-associated multisystem inflammatory conditions. The higher rate of positive serologic tests compared with nasopharyngeal reverse transcription-polymerase chain reaction (RT-PCR) is suggestive of a late complication of the disease. Pathophysiology of MIS-C is still unclear and possible mechanisms include antibody or T-cell recognition of self-antigens (viral mimicry of the host) resulting in autoantibodies, antibody or T-cell recognition of viral antigens expressed on infected cells, formation of immune complexes which activate inflammation, and viral super-antigen sequences which activate host immune cells [16] [17]. IgM antibodies are detectable within 5 days of infection, with higher IgM levels during weeks 2 - 3 of illness, while IgG response is first seen approximately 14 days after symptom onset.

The presenting cases had in common a family story of COVID-19 disease in 2 - 4 previous months. Nasopharyngeal reverse transcription-polymerase chain reaction (RT-PCR) for COVID-19 was negative, IgM antibodies results were negative, and IgG antibodies results were positive. Children appeared moderately ill. Fever was present in all cases, in 2 - 5 days duration. They were hemodynamically stable, and no gastro-intestinal symptoms were reported. The most remarkable sign were the skin eruptions. The initial lesion was a dull-red, purpuric macule or urticarial plaque, distributed initially on the face, neck and trunk and then on the extremities. The lesions gradually changed to become cyanotic or violaceous, leaving a post-inflammation hyperpigmentation. The Nikolsky sign was negative and the children experienced no pruritus. Oropharyngeal injection was present in all of them and the two infants had a strawberry

Table 1. CDC case definition for multisystem inflammatory syndrome in children (MIS-C) [16].

1) An individual aged $<21$ years with

2) Clinical criteria:

_ A minimum 24-h history of subjective or objective fever _ 38.0_C AND

_ Severe illness necessitating hospitalization AND

_ Two or more organ systems affected (i.e., cardiac, renal, respiratory, hematologic, gastrointestinal, dermatologic, neurological)

3) Laboratory evidence of inflammation

_ One or more of the following: an elevated CRP, ESR, fibrinogen, procalcitonin, D-dimer, ferritin, LDH, or IL-6; elevated neutrophils or reduced; low albumin

4) Laboratory or epidemiologic evidence of SARS-CoV-2 infection

_ Positive SARS-CoV-2 testing by RT-PCR, serology, or antigen OR

_ COVID-19 exposure within 4 weeks prior to onset of symptoms

5) No alternative diagnosis

Abbreviations: CDC, Centers for Disease Control; CRP, C-reactive protein; ESR, erythrocyte sedimentation rate; LDH, lactate dehydrogenase; RT-PCR, reverse transcriptase polymerase chain reaction; SARS-CoV-2, severe acute respiratory syndrome coronavirus-2 
tongue. Leukocytosis with neutrophilia was found in all cases. C Reactive Protein (CRP) was increased in all cases and D-dimer was increased in three of them. Blood cultures were all negative. Platelets were in normal values except two cases where platelets count increased in the second week of the disease. Thrombocytosis is not typical in MISC, otherwise it is companied by thrombocytopenia. Thrombocytosis in children are usually reactive, particularly common during recovery phase of an infection or inflammation and are usually transient and subsides when the primary stimulus ceases. Reactive thrombocytosis is usually mediated by increased release of numerous cytokines in response to infections. A wide range of cytokines may participate in the stimulation of platelet production, IL-3, IL-11, granulocyte-macrophage colony-stimulating factor, erythropoietin but the most imported role is plaid by thrombopoietin and IL- 6 which are initially elevated in response to infections [18].

Prednisolone was used in all cases from 3 - 5 days. Erythema faded and inflammatory parameters stabilized in 1 week. Considering all the data of the presented cases, it was assumed to be a late inflammatory reaction to COVID-19 infection. Initially it seemed as the children were developing MISC, as some criteria of MISC matched, but somehow the immune dysregulation did not reach the magnitude to cause a full-blown MISC, and skin resulted the only organ involved.

\section{Conclusion}

It is now clear that children of any age may be infected with SARS-CoV-2. They suffer a less severe acute infection compared to adults, but the immune dysregulation that follows, pose the children at risk of late inflammatory reactions that sometimes may be life-threatening. Skin rashes may be the presenting feature of a late post COVID-19 immune reaction. As the pandemic continues to evolve, it is still hard to predict the mid and long term effects on children health and well-being.

\section{Acknowledgements}

We thank all the medical staff of the General Pediatric Ward for the constant support!

\section{Conflicts of Interest}

The authors declare no conflicts of interest regarding the publication of this paper.

\section{References}

[1] Dong, Y., Mo, X., Hu, Y., Qi, X., Jiang, F. and Jiang, Z. (2020) Epidemiology of COVID-19 among Children in China. Pediatrics, 145, e20200702. https://doi.org/10.1542/peds.2020-0702

[2] Bialek, S., Gierke, R., Hughes, M., McNamara, L.A., Pilishvili, T. and Skoff, T. (2020) Coronavirus Disease 2019 in Children-United States, February 12-April 2, 
2020. Morbidity and Mortality Weekly Report, 69, 422-426.

https://www.cdc.gov/mmwr/volumes/69/wr/mm6914e4.htm https://doi.org/10.15585/mmwr.mm6914e4

[3] Lu, X., Zhang, L., Du, H., Zhang, J., Li, Y.Y., Qu, J., et al. (2020) SARS-CoV-2 Infection in Children. The New England Journal of Medicine, 382, 1663-1665.

http://www.nejm.org/doi/10.1056/NEJMc2005073

https://doi.org/10.1056/NEJMc2005073

[4] Götzinger, F., Santiago-García, B., Noguera-Julián, A., Lanaspa, M., Lancella, L. and Carducci, F.I.C. (2020) COVID-19 in Children and Adolescents in Europe: A Multinational, Multicentre Cohort Study. The Lancet Child \& Adolescent Health, 4, 653-661.

[5] Huang, C., Wang, Y., Li, X., Ren, L., Zhao, J., Hu, Y., et al. (2020) Clinical Features of Patients Infected with 2019 Novel Coronavirus in Wuhan, China. The Lancet, 395, 497-506. https://doi.org/10.1016/S0140-6736(20)30183-5

[6] Mehta, P., McAuley, D.F., Brown, M., Sanchez, E., Tattersall, R.S. and Manson, J.J. (2020) COVID-19: Consider Cytokine Storm Syndromes and Immunosuppression. The Lancet, 395, 1033-1034.

https://www.ncbi.nlm.nih.gov/pmc/articles/PMC7270045/

https://doi.org/10.1016/S0140-6736(20)30628-0

[7] Hoffmann, M., Kleine-Weber, H., Schroeder, S., Krüger, N., Herrler, T., Erichsen, S., et al. (2020) SARS-CoV-2 Cell Entry Depends on ACE2 and TMPRSS2 and Is Blocked by a Clinically Proven Protease Inhibitor. Cell, 181, 271-280.e8. https://doi.org/10.1016/j.cell.2020.02.052

[8] Walsh, K.A., Jordan, K., Clyne, B., Rohde, D., Drummond, L., Byrne, P., et al. (2020) SARS-CoV-2 Detection, Viral Load and Infectivity over the Course of an Infection. Journal of Infection, 81, 357-371. https://doi.org/10.1016/j.jinf.2020.06.067

[9] Heald-Sargent, T., Muller, W.J., Zheng, X., Rippe, J., Patel, A.B. and Kociolek, L.K. (2020) Age-Related Differences in Nasopharyngeal Severe Acute Respiratory Syndrome Coronavirus 2 (SARS-CoV-2) Levels in Patients with Mild to Moderate Coronavirus Disease 2019 (COVID-19). JAMA Pediatrics, 74, 902-903.

https://jamanetwork.com/ https://doi.org/10.1001/jamapediatrics.2020.3651

[10] Liguoro, I., Pilotto, C., Bonanni, M., Ferrari, M.E., Pusiol, A., Nocerino, A., Vidal, E. and Cogo, P. (2020) SARS-COV-2 Infection in Children and Newborns: A Systematic Review. European Journal of Pediatrics, 179, 1029-1046.

https://doi.org/10.1007/s00431-020-03684-7

[11] Parri, N., Lenge, M. and Buonsenso, D. (2020) Children with COVID-19 in Pediatric Emergency Departments in Italy. The New England Journal of Medicine, 383, 187-190. http://www.nejm.org/doi/10.1056/NEJMc2007617 https://doi.org/10.1056/NEJMc2007617

[12] Carsetti, R., Quintarelli, C., Quinti, I., Piano Mortari, E., Zumla, A., et al. (2020) The Immune System of Children: The Key to Understanding SARS-CoV-2 Susceptibility? The Lancet Child \& Adolescent Health, 4, 414-416. https://doi.org/10.1016/S2352-4642(20)30135-8

[13] Yuki, K., Fujiogi, M. and Koutsogiannaki, S. (2020) COVID-19 Pathophysiology: A Review. Clinical Immunology, 215, Article ID: 108427

https://pubmed.ncbi.nlm.nih.gov/32325252/ https://doi.org/10.1016/j.clim.2020.108427

[14] Godfred-Cato, S., Bryant, B., Leung, J., Oster, M.E., Conklin, L., Abrams, J., et al. 
(2020) COVID-19-Associated Multisystem Inflammatory Syndrome in Children-United States, March-July 2020. Morbidity and Mortality Weekly Report, 69, 1074-1080.

http://www.cdc.gov/mmwr/volumes/69/wr/mm6932e2.htm?s_cid=mm6932e2_w https://doi.org/10.15585/mmwr.mm6932e2

[15] Feldstein, L.R., Rose, E.B., Horwitz, S.M., Collins, J.P., Newhams, M.M., Son, M.B.F., et al. (2020) Multisystem Inflammatory Syndrome in U.S. Children and Adolescents. The New England Journal of Medicine, 383, 334-346.

[16] Nakra, N.A., Blumberg, D.A., Herrera-Guerra, A. and Lakshminrusimha, S. (2020) Multi-System Inflammatory Syndrome in Children (MIS-C) Following SARS-CoV-2 Infection: Review of Clinical Presentation, Hypothetical Pathogenesis, and Proposed Management. Children (Basel), 7, 69.

http://www.ncbi.nlm.nih.gov/pubmed/32630212

https://doi.org/10.3390/children7070069

[17] Jiang, L., Tang, K., Levin, M., Irfan, O., Morris, S.K., Wilson, K., et al. (2020) COVID-19 and Multisystem Inflammatory Syndrome in Children and Adolescents. The Lancet Infectious Diseases, 20, e276-e288.

https://pubmed.ncbi.nlm.nih.gov/32818434/ https://doi.org/10.1016/S1473-3099(20)30651-4

[18] Zheng, S.Y., Xiao, Q.Y., Xie, X.H., et al. (2016) Association between Secondary Thrombocytosis and Viral Respiratory Tract Infections in Children. Scientific Reports, 6, Article No. 22964. https://doi.org/10.1038/srep22964 